\title{
The Impact of Pre-Competition Estimated Results for Elite Archers on Performance According to Achievement Goal Theory
}

\author{
Utku Isik ${ }^{1, *}$ \\ ${ }^{1}$ Recep Tayyip Erdogan University, School of Physical Education and Sport, Rize, Turkey \\ *Correspondence: School of Physical Education and Sports, Recep Tayyip Erdogan University, Rize, Turkey, Tel: \\ 90-464-223-6070. E-mail: utku.isik@erdogan.edu.tr
}

Received: July 17, 2018

Accepted: August 2, $2018 \quad$ Online Published: August 24, 2018

doi:10.5430/wje.v8n4p146

URL: https://doi.org/10.5430/wje.v8n4p146

\begin{abstract}
This study aimed to evaluate the estimated/judged results for elite archers before competitions in the context of Achievement Goal Theory and determine its impact on actual performance. Also, the study assessed the impact of goal orientation on the competition scores to comprehend the relationship between goal orientation and performance. Study participants were 116 elite archers who participated in Adult-Youth Indoor Turkey Championship in Izmir. Before the competition, the participants filled in the "Task and Ego Orientation in Sport Questionnaire". Before this scale, a survey form, developed by the researcher, was given to participants to learn about their personal characteristics. The participants were asked to make a note of the numbers they wore on the chest of their uniforms and the predicted/judged scores on the survey form. They were informed that at the termination of the competition, their actual scores and their predicted scores would be compared. The study presents two important results. The first result is related to the fact that athletes with high goal orientation were significantly more successful than those with low goal orientation in a real competition environment. The other result of in the current study was the significant relationship between the pre-competition predictions/estimates of individuals with high goal orientation and their competition performances. This study is significant because it demonstrated that individuals with higher goal orientations have higher performances and that their predictions/estimates for their performance are much more accurate.
\end{abstract}

Keywords: estimated performance, achievement goal theory, archers

\section{Introduction}

The term "motivation" points to the force that activates us, helps us sustain our actions and supports the commencement and completion of tasks" (Pintrich \& Schunk, 1996). As can be comprehended from the general definition of motivation in the dictionary, level of motivation is very important to complete tasks and achieve good results. Real success is accompanied by high motivation (Agbuga \& Xiang, 2008; Agbuga, Xiang, \& McBride, 2010). One of the most prominent theories of motivation (Anderman \& Wolters, 2006; Ma \& Monsma, 2016) is the achievement goal theory (AGT) (Nicholls 1984, 1989). Sports field is the area where the impact of motivation on success can be best observed. During the last half-century, scientists working in the field of sports and exercise psychology have placed achievement goal theory in the center of their work for different purposes. Tok, Dal, Doğan, Yaman and Binboğa (2017) cited that based on AGT; individuals have two different goal perspectives or subjective success perceptions. Therefore, AGT claims that there are two motivational (or goal) orientations and these depend on an athlete's interpretation of success (Moran, 2004). Accordingly, mastery (or task) oriented individuals will feel successful when they develop their own abilities through task mastery and skill development; performance (or ego) oriented individuals will only feel successful when they demonstrate their own competence relative to others (Buch, Nerstad, Aandstad, \& Säfvenbom, 2016; Roberts, 2012, Tok et al., 2017). Task-oriented goals allow athletes to develop their skills via knowledge and task mastery. Ego oriented goals strengthens athletes' sense of competence by comparing them with others. While task orientation is related to adaptive motivational designs, ego orientation is associated with maladaptive motivational variables (Ames, 1992a, 1992b; Duda, 1992). Moreover, task-oriented athletes believe that success comes from effort, cooperation and intrinsic interest whereas ego-oriented athletes believe that success is related to deception and superior abilities (Solmon, 1996; Agbuga, 2014). 
In recent years, a substantial number of studies have been conducted in the field of education and psychology to compare athletes' or students' judged/estimated performances with their actual performances. Kolovelonis and Goudas (2018) cited that students' awareness for learning and performance are enhanced by metacognitive feelings and estimates (such as learning judgments) in task involvement (before, during, or after) (Efklides, 2011). In this context, judgment of performance is regarded as metacognitive in nature as well and it is believed to result from conscious processing of instructions, task characteristics, and metacognitive knowledge in regards to ability to use effective strategies (Efklides, 2009). Educational contexts mostly use difference scores between estimated/judged performance and actual performance to measure absolute accuracy (Chen \& Rossi, 2013). This paradigm is used in sports field as well as in education. Performance estimates in the field of sports may help athletes to assess their performances, know about their abilities and determine their targets more comfortably. Participants' judged and actual performances were compared in different sportive activities such as golf shots (Fogarty \& Else, 2005), free shots of recreational basketball players (McGraw, Mellers, \& Ritov, 2004), dart shots (Gasser \& Tan, 2005) and students' free basketball shots (Kolovelonis \& Goudas, 2018). Since metacognitive judgments might demonstrate stable trait-like characteristics (Pieschl, 2009), person related characteristics may also be effective in individual differences in calibration. Similarities between estimates and actual performances may be due to different characteristics of the athletes.

While there are various studies conducted with AGT framework in sports psychology in different fields with different methods (Allen, Taylor, Dimeo, Dixon, \& Robinson, 2015; Tok et al., 2017; Elferink-Gemser et al., 2016; Vieira et al.2015; Lee, 2014; Pelletier, Rocchi, Vallerand, Deci, \& Ryan, 2013; Machida, Ward \& Vealey,2012; Gomes, Martins, \& Silva, 2011; Silva, Gomes, \& Martins, 2011; Elbe, Madsen, \& Midtgaard, 2010; Stuntz \& Weiss, 2015); there are only a handful of studies where calibration has been used. Goal orientation is associated with self-regulation and metacognition (Efklides, 2011). Task-oriented students who focus on skill mastery may be involved in metacognitive processes (such as self-monitoring) while ego-oriented students who mostly focus on performing better than others may not be engaged in these processes at all (Pintrich, 2000; Vrugt \& Oort, 2008). Bring aware of their own skills is one of the most important advantages for athletes in achieving their objectives. Athletes who are aware of their own potential and abilities will be more realistic when they identify their objectives and when they try to realize these objectives. The literature review conducted in this framework has determined that a limited number of studies that investigates the relationship between AGT and calibration exits in the field of sports (Kolovelonis \& Goudas, 2018; Chao, 2014). Also, comparative studies mostly focused on amateur athletes and students and they used experimental designs rather than actual competitions.

This study aimed to evaluate the estimated/judged results for elite archers before competitions in the context of Achievement Goal Theory and determine its impact on actual performance. Also, the study assessed the impact of goal orientation on the competition scores to comprehend the relationship between goal orientation and performance.

\section{Method}

\subsection{Participants}

Study participants were 116 elite archers who participated in Adult-Youth Indoor Turkey Championship in Izmir (Mean age $=33.29, \mathrm{SD}=1.26,82$ males and 34 females). Athletes that compete in the Turkey Championship are the athletes who have been successful in competitions held regionally. All participants were informed of the study and their participation was voluntary.

\subsection{Motivational (Goal) Orientation Measures}

A Turkish version of the Task and Ego Orientation in Sport Questionnaire (TEOSQ) was used to measure participants' motivational orientations. The TEOSQ consists of a series of 13 questions: 7 questions evaluate task orientation and 6 questions evaluate ego orientation. Participants responded on a 5-point Likert-type scale with anchors of not at all (1), strongly disagree (2), disagree (3), neutral (4), and strongly agree (5). The TEOSQ was adapted into Turkish by Toros (2004).

Before the competition, the participants filled in the "Task and Ego Orientation in Sport Questionnaire". Before this scale, a survey form, developed by the researcher, was given to participants to learn about their personal characteristics. The participants were asked to make a note of the numbers they wore on the chest of their uniforms and the predicted/judged scores on the survey form. They were informed that at the termination of the competition, their actual scores and their predicted scores would be compared. The athletes who did not want to share their competition numbers or their predicted scores were excluded from the study. 


\subsection{Statistical Analyses}

The obtained data were analyzed using descriptive statistical methods such as frequency and percentage in accordance with the aims of the study and also inferential statistical methods were utilized. The hierarchical and non-hierarchical clustering analysis was used to classify the target orientation levels of the athletes. Ward Method was applied in hierarchical clustering methods. The squared euclidean distance was used in the Ward method. One-Way Anova test was used to reveal the differences between the clusters. Linear regression analysis was utilized to examine the effect of the predicted score on the outcome of the competition.

\section{Findings}

The agglomeration table obtained by using the squared Euclidean distance coefficients in the hierarchical clustering analysis was investigated. The distance coefficients in the agglomeration table can be considered as a measure to determine the number of sets in the clusters. (Nakip, 2006). In this direction, results of analysis demonstrated two large jumps in the last two steps of the coefficients. Although the two clusters were thought to be appropriate based on this finding, the tree diagram (dendrogram) was also carefully examined with the reason that it is used as a means to determine the number of clusters (Nakip, 2006).

As shown in the tree diagram below, 166 participants were clustered in two groups in general. Therefore, the optimal number of clusters was found to be two based on the agglomeration table and tree diagram(see Appendix).

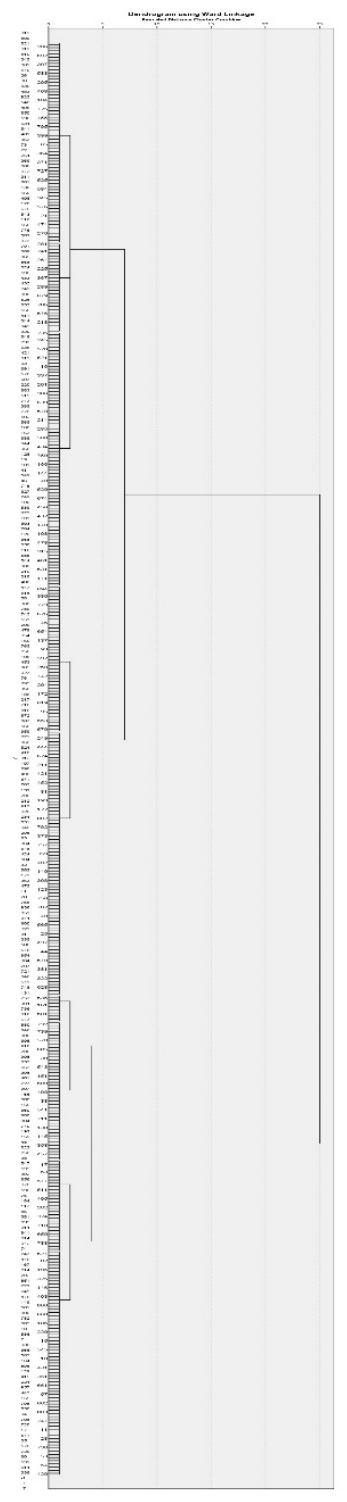


In terms of reliability of the clustering solutions; K-means cluster, which is a non-hierarchical clustering method, was applied after the hierarchical clustering analysis and the optimal number of clusters was decided after this analysis. In this method, observations are placed in different clusters with the greatest variability among the clusters and the smallest in-cluster variability. The aim of this method is to divide the observations into a number of clusters determined by the researcher (Alpar, 2011). Since the number of clusters in the hierarchical clustering method was found to be two, the number of clusters was set to two when K-means clustering was applied and the analysis is performed.

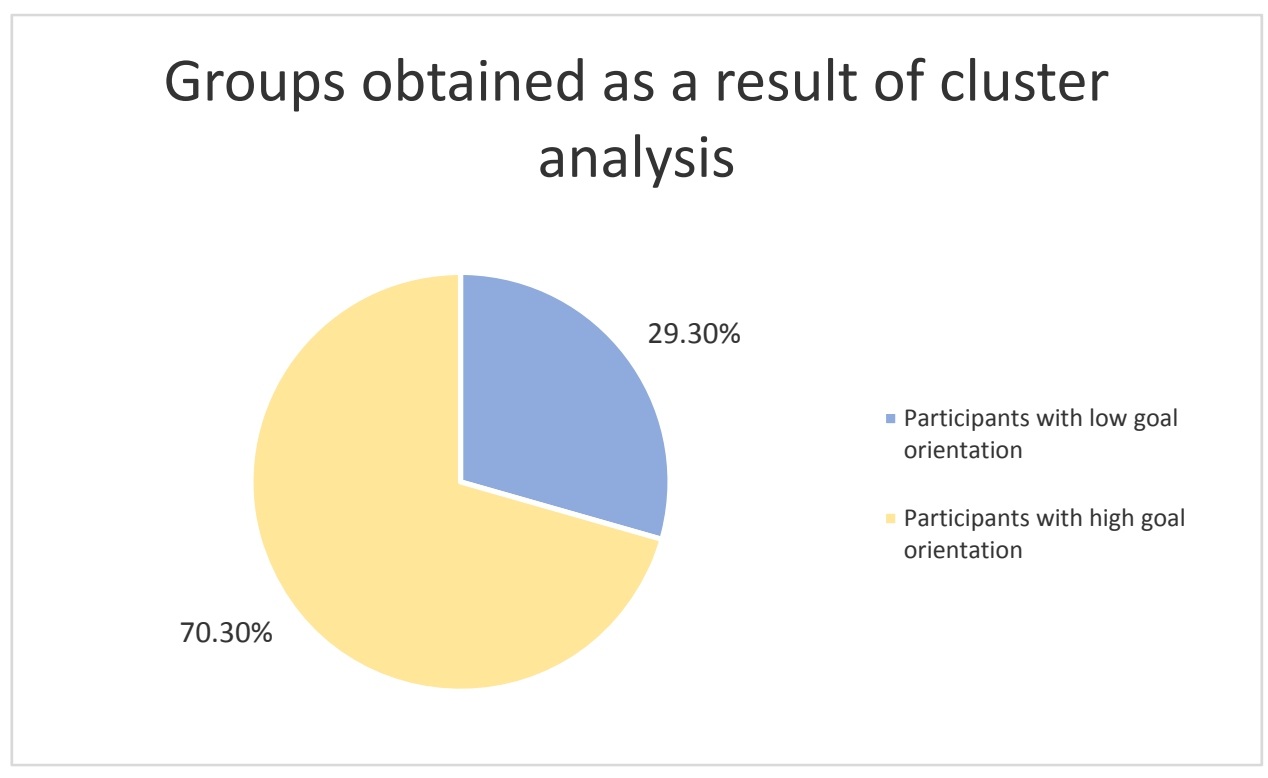

Graph 1. Groups Obtained as a Result of Cluster Analysis

Table 1. The Average of the 13 Questions in Clusters and the Results of the One-Way Variance Test.

\begin{tabular}{|c|c|c|c|c|c|c|}
\hline & \multicolumn{2}{|c|}{ Cluster 1} & \multicolumn{2}{|c|}{ Cluster 2} & \multirow[b]{2}{*}{$\mathrm{F}$} & \multirow[b]{2}{*}{ Sig. } \\
\hline & Mean & $\mathrm{SD}$ & Mean & SD & & \\
\hline S1 & 25,084 & 5,22 & 0,866 & 0,32 & 28,951 & 0,000 \\
\hline $\mathrm{S} 2$ & 22,892 & 4,19 & 0,590 & 0,25 & 38,802 & 0,000 \\
\hline $\mathrm{S} 3$ & 24,737 & 4,46 & 0,654 & 0,43 & 37,804 & 0,000 \\
\hline $\mathrm{S} 4$ & 56,327 & 9,87 & 0,494 & 0,21 & 113,915 & 0,000 \\
\hline S5 & 17,164 & 3,86 & 0,615 & 0,49 & 27,910 & 0,000 \\
\hline S6 & 17,999 & 3,72 & 0,482 & 0,24 & 37,352 & 0,000 \\
\hline S7 & 7,925 & 1,89 & 0,419 & 0,11 & 18,920 & 0,000 \\
\hline S8 & 7,537 & 1,15 & 0,464 & 0,18 & 16,247 & 0,000 \\
\hline S9 & 4,260 & 1,62 & 0,592 & 0,29 & 7,200 & 0,000 \\
\hline $\mathrm{S} 10$ & 15,204 & 3,14 & 0,434 & 0,19 & 35,021 & 0,000 \\
\hline S11 & 7,428 & 1,78 & 0,525 & 0,23 & 22,823 & 0,000 \\
\hline $\mathrm{S} 12$ & 11,709 & 2,28 & 0,418 & 0,13 & 28,028 & 0,000 \\
\hline $\mathrm{S} 13$ & 6,975 & 1,12 & 0,615 & 0,33 & 11,347 & 0,000 \\
\hline
\end{tabular}

The Table demonstrates the results of the analysis: the average of the 13 questions in clusters, the results of the one-way variance test and the number of observations in each cluster. Examination of one was variance analysis that was conducted to see whether there was a meaningful difference between the clusters in terms of the questions shows that there were differences in the questions based on clusters $(\mathrm{p}<.05)$; which is a desirable result and is natural. Clustering analysis created this difference itself and maximized the difference between clusters. In other words, the distribution of observations in these clusters was not random (Kalayc1, 2010; Nakip, 2006). Therefore, there were 34 
$(29.3 \%)$ and $82(70.7 \%)$ participants in the first and second clusters respectively and the difference between the clusters was found to be significant at .05 level $(\mathrm{p}<0.05)$.

Table 2. Athletes with Low Goal Orientation

\begin{tabular}{llllll}
\hline Variable & B & SE & Beta & t & p \\
\hline (Constant) & 221,214 & 257,779 & & 0,858 & 0,406 \\
Pre-competition Estimated Score & 0,169 & 0,241 & 0,257 & 0,704 & 0,494 \\
F=.825; R2:160; $p>0,05$ & & & & & \\
\hline
\end{tabular}

Table 3. Athletes with High Goal Orientation

\begin{tabular}{llllll}
\hline Variable & B & SE & Beta & t & $p$ \\
\hline (Constant) & 456,823 & 68,768 & & 6,643 & 0,000 \\
Pre-competition Estimated Score & 0,986 & 0,292 & 1,659 & 3,374 & 0,002 \\
F:4,173; R=603; R2:305; $\mathrm{p}<0,05$ & & & & & \\
\hline
\end{tabular}

While pre-competition estimates of participants with low goal orientations had no impact on their performances $\left(\mathrm{F}=, 825 ; \mathrm{R}=400 ; \mathrm{R}^{2}=160 ; \mathrm{p}>0,05\right)$, clustering analysis results show that pre-competition score estimates of participants with high goal orientations affected competition results $\left(F=4,173 ; R=603 ; R^{2}=305 ; p<0,05\right)$. The scores predicted by the participants prior to the competition alone account for $30 \%$ of the total variance for the result of the competition.

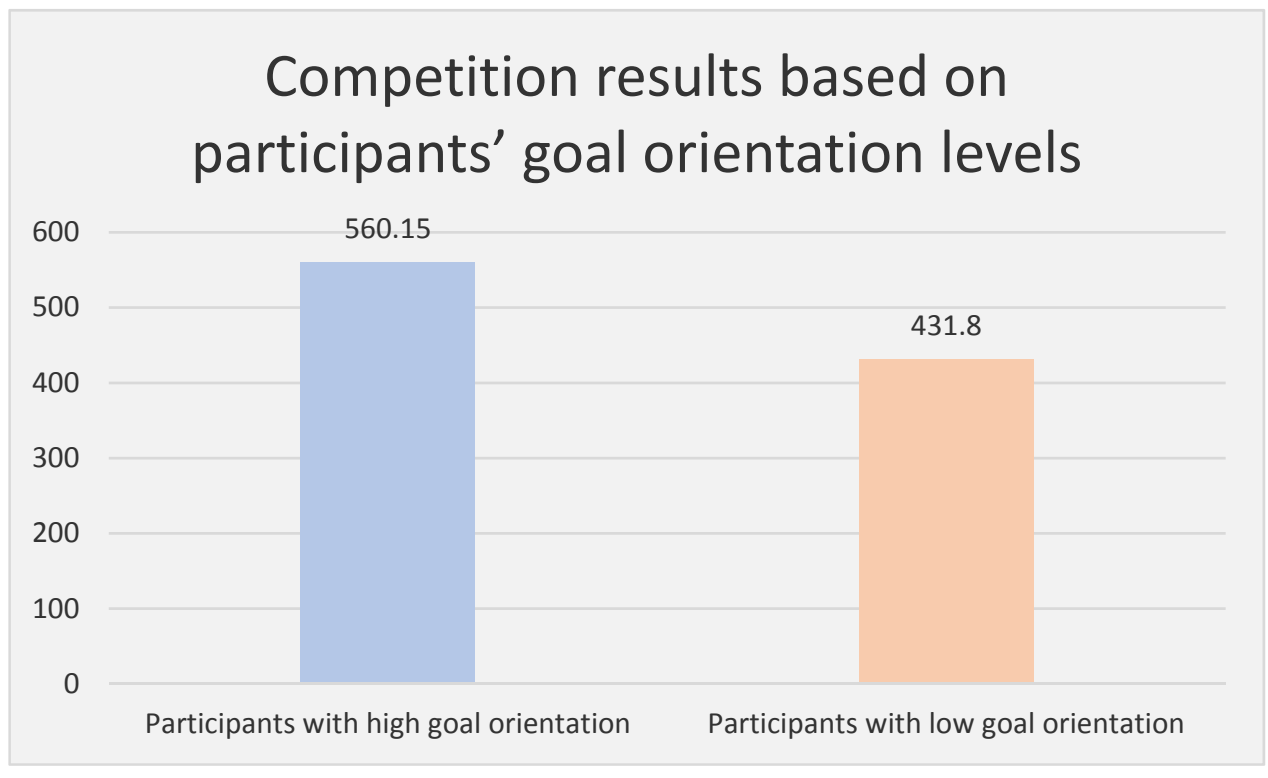

Graph 2. Competition Results Based on Participants' Goal Orientation Levels

There was also a significant difference between the scores of participants with low and high goal orientation at the end of the competition ( $t=2,849 ; \mathrm{p}<0,05)$. The athletes with higher goal orientations had significantly higher averages compared to the athletes with lower competition scores.

\section{Discussion}

This study aimed to investigate pre-competition estimated scores for elite archers in terms of Achievement Goal Theory on determine its impact on performance. Additionally, the study aimed to present the impact of goal orientation levels on post-competition scores to determine the relationship between goal orientation and performance.

The study presents two important results. The first result is related to the fact that athletes with high goal orientation were significantly more successful than those with low goal orientation in a real competition environment. There are recent studies which focused on the influence of goal orientation on business performance in addition to sports 
performance (Domingues, Vieira, \& Agnihotri, 2017; Blau, Petrucci, \& Rivera, 2018; Johnson et al.,2018; Zhang, Jex, Peng, \& Wang, 2017; Shin, Kim, \& Lee, 2016). Positive impact of high goal orientation levels on achievement in students has also been investigated by educators in different aspects (Nasiri, Pour-Safar, Taheri, Pashaky, \& Louyeh, 2017; Poondej \& Lerdpornkulrat, 2016; Akpur, 2016; Kaur, Noman, \& Awang-Hashim, 2018). The current study is significant since it presents the positive impact of goal orientation in sports environments in an actual competition setting. Sports is one of the fields where the impact of goal orientation on performance can easily be observed. Many investigators have studies the positive impact of athletes' goal orientation levels on their performances.

In their study conducted with ice hockey athletes, Jaakkola, Ntoumanis, \& Liukkonen (2016) found that groups with higher sports skills had higher task related motivational climate and that motivational climate was positively associated with personal development and improvement as well as individual effort. Similar to the current study, Wang, Chatzisarantis, Spray, \& Biddle (2002) reported that high motivation, high task orientation and high ego orientation for physical activity were related to high levels of perceived competence. Professional athletes were found to be aware that goal orientation levels had significant impact on their achievement (Fernández-Río, Cecchini, Méndez-Giménez, Terrados, \& García, 2018). The current study did not examine the effect of task and ego orientations on individual performance separately. Studies in various fields have pointed that goal-oriented individuals display higher performance compared to ego oriented individuals. It is known that task-oriented goals support positive outcomes in conceptual learning as well (Mupira \& Ramnarain, 2017). However, goal orientation involves both ego and task orientation and the athletes usually encounter both motivational climate conditions in sporting environments. In this sense, it is more meaningful to study the influence of the (high or low) goal orientation alone on performance.

The other result of in the current study was the significant relationship between the pre-competition predictions/estimates of individuals with high goal orientation and their competition performances. In other words, predictions/estimates of athletes with high goal orientation positively influenced the actual competition scores. Studies in literature separately investigated task and ego orientations to find which orientation led to better estimates. It was found that feedback was provided by task-oriented students to develop themselves and become aware of their learning (Pintrich, 2000) and they could judge their performance objectively and perform calibration better (Stone, 2000). Ego-oriented students tended to demonstrate their abilities and therefore they were expected to have higher performance estimates (Kroll \& Ford, 1992). In their study with 236 elementary school students, Kolovelonis \& Goudas (2018) found that students with higher task orientation performed better than students with higher ego orientation in estimating free shots in basketball. Also, in Choa's (2014) study; correlational analyses showed that high-mastery oriented players were more accurate in their estimates of performance (better calibrated), while high-performance oriented players were more confident in their estimates.

This study is significant because it demonstrated that individuals with higher goal orientations have higher performances and that their predictions/estimates for their performance are much more accurate. Since students' and athletes' goal orientations are affected by the behaviors of coaches and parents (Schwebel, Smith, \& Smoll, 2016), their role in the path to success is crucial. In today's world, where students and athletes have to perform multiple tasks, it is necessary to consider their predictions/prejudices in regards to their performance in specific tasks. While goal orientation is not necessarily related to achievement, calibration bias may be an important factor in regulating students' and athletes' achievement goals (Muis, Winne, \& Ranellucci, 2016).

\section{Conclusion}

Predicting and being aware of performance will lead to much more realistic planning in regards to performance. In this manner, athletes will be able to design their work and training plans based on these facts. Future goals of students and athletes with no awareness of their performances will not be very realistic and easy to achieve. The goal orientation and motivational climate level are keys in this respect since they can demonstrate this awareness clearly.

\section{References}

Agbuga, B. (2014). Beden Eğitimi Derslerinde Türk Öğrencilerinin Algılanan Motivasyonel İklim ve Israr/Eforları Hakkında Görüşleri. Eğitim ve Bilim, 39(175).

Agbuga, B., \& Xiang, P. (2008). Achievement goals and their relations to self-reported persistence/effort in secondary physical education: A trichotomous achievement goal framework. Journal of Teaching in Physical Education, 27(2), 179-191. https://doi.org/10.1123/jtpe.27.2.179 
Agbuga, B., Xiang, P., \& McBride, R. (2010). Achievement goals and their relations to children's disruptive behaviors in an after-school physical activity program. Journal of Teaching in Physical Education, 29(3), 278-294.

Akpur, U. (2016). The explanatory and predictive relationship pattern between university students goal orientation behaviours and their academic achievement. Educational Research and Reviews, 11(17), 1650-1658. https://doi.org/10.5897/ERR2016.2878

Allen, J., Taylor, J., Dimeo, P., Dixon, S., \& Robinson, L. (2015). Predicting elite Scottish athletes' attitudes towards doping: examining the contribution of achievement goals and motivational climate. Journal of sports sciences, 33(9), 899-906. https://doi.org/10.1080/02640414.2014.976588

Alpar, R. (2011). Uygulamalı Çok Değişkenli İstatistiksel Yöntemler. Detay Yayıncılık, Üçüncü Baskı, Ankara.

Ames, C. (1992a). Classrooms: Goals, structures, and student motivation. Journal of Educational Psychology, 84, 261-267. https://doi.org/10.1037/0022-0663.84.3.261

Ames, C. (1992b). Achievement goals, motivational climate, and motivational climate and motivational processes. In G. Roberts (ED.), Motivation in Sport and Exercise (pp. 161-176). Champaign, IL: Human Kinetics.

Anderman, E. M., \& Wolters, C. A. (2006). Goals, values and affect: Influences on student motivation. In P. Alexander \& P. Winne (Eds.), Handbook of educational psychology (2nd ed., pp. 369-389). Mahwah, NJ: Lawrence Erlbaum.

Blau, G., Petrucci, T., \& Rivera, M. (2018). Correlates of state goal orientation for an MBA team project using a real-time performance feedback mobile application. Journal of Education for Business, 93(4), 155-164. https://doi.org/10.1080/08832323.2018.1439875

Buch, R., Nerstad, C. G., Aandstad, A., \& Säfvenbom, R. (2016). Exploring the interplay between the motivational climate and goal orientation in predicting maximal oxygen uptake. Journal of Sports Sciences, 34(3), 267-277. https://doi.org/10.1080/02640414.2015.1048522

Chao, F. (2014). Calibration and achievement goals in college volleyball. George Mason University (Master thesis).

Chen, P., \& Rossi, P. (2013). Utilizing calibration accuracy information with adolescents to improve academic learning and performance. In H. Bembenutty, T. Cleary, \& A. Kitsantas (Eds.), Applications of self-regulated learning across diverse disciplines: A tribute to Barry J. Zimmerman (pp. 263-297). Information Age: Greenwich, CT.

Domingues, J., Vieira, V. A., \& Agnihotri, R. (2017). The interactive effects of goal orientation and leadership style on sales performance. Marketing Letters, 28(4), 637-649. https://doi.org/10.1007/s11002-017-9436-3

Duda, J. L. (1992). Motivation in sport settings: A goal perspective approach. In G. Roberts (Ed.), Motivation in sport and exercise (pp.57-92). Champaign, IL: Human Kinetics.

Efklides, A. (2009). The role of metacognitive experiences in the learning process. Psicothema, 21, 76-82.

Efklides, A. (2011). Interactions of metacognition with motivation and affect in selfregulated learning: The MASRL model. Educational Psychologist, 46, 6-25. http://dx.doi.org/10.1080/00461520.2011.538645

Elbe, A., Madsen, C., \& Midtgaard, J. (2010). A cross-cultural comparison of motivational factors in Kenyan and Danish middle and long distance elite runners. Journal of Psychology in Africa, 20(3), 421-428. https://doi.org/10.1080/14330237.2010.10820394

Elferink-Gemser, M.T., Roos, I.D., Torenbeek, M., Fokkema, T., Jonker, L., \& Visscher, C. (2016). The importance of psychological constructs for training volume and performance improvement. A structural equation model for youth speed skaters. International Journal of Sport Psychology, 47(1), 726-744.

Fernández-Río, J., Cecchini, J. A., Méndez-Giménez, A., Terrados, N., \& García, M. (2018). Understanding olympic champions and their achievement goal orientation, dominance and pursuit and motivational regulations: A case study. Psicothema, 30(1), 46-52.

Fogarty, G., \& Else, D. (2005). Performance calibration in sport: Implications for selfconfidence and metacognitive biases. International Journal of Sport and Exercise Psychology, 3, 41-57. http://dx.doi.org/10.1080/1612197X.2005.9671757

Gasser, M., \& Tan, R. (2005). Performance estimates and confidence calibration for a perceptual-motor task. North American Journal of Psychology, 7, 457-468. 
Gomes, A.R., Martins, C., \& Silva, L. (2011). Eating disordered behaviours in Portuguese athletes: The influence of personal, sport, and psychological variables. European Eating Disorders Review, 19(3), 190-200. http://dx.doi.org/10.1002/erv.1113

Jaakkola, T., Ntoumanis, N., \& Liukkonen, J. (2016). Motivational climate, goal orientation, perceived sport ability, and enjoyment within F innish junior ice hockey players. Scandinavian journal of medicine \& science in sports, 26(1), 109-115. https://doi.org/10.1111/sms.12410

Johnson, S. K., Putter, S., Reichard, R. J., Hoffmeister, K., Cigularov, K. P., Gibbons, A. M., ... \& Rosecrance, J. C. (2018). Mastery Goal Orientation and Performance Affect the Development of Leader Efficacy During Leader Development. Journal of Leadership \& Organizational Studies, 25(1), 30-46. https://doi.org/10.1177/1548051817713689

Kaur, A., Noman, M., \& Awang-Hashim, R. (2018). The role of goal orientations in students' perceptions of classroom assessment in higher education. Assessment \& Evaluation in Higher Education, 43(3), 461-472. https://doi.org/10.1080/02602938.2017.1359818

Kolovelonis, A., \& Goudas, M. (2018). The relation of physical self-perceptions of competence, goal orientation, and optimism with students' performance calibration in physical education. Learning and Individual Differences, 61, 77-86. https://doi.org/10.1080/02602938.2017.1359818

Lee, A. (2014). Comparisons of achievement goal orientation and their relationship to character in high school students and athletes: Quantitative and qualitative approaches. Journal of Korean Sport Science and Physical Education, 18(4), 83-98.

Ma, C., \& Monsma, E. (2016). Testing cross-cultural generalizability of the task and ego orientation in sport questionnaire across American and Chinese samples. PloS one, 11(7), e0158953. https://doi.org/10.1371/journal.pone.0158953

Machida, M., Marie Ward, R., \& Vealey, R.S. (2012). Predictors of sources of self-confidence in collegiate athletes. International Journal of Sport \& Exercise Psychology, 10(3), 172-185. http://dx.doi.org/10.1080/1612197x.2012.672013

McGraw, A., Mellers, B., \& Ritov, I. (2004). The affective cost of overconfidence. Journal of Behavioral Decision Making, 17, 281-295. http://dx.doi.org/10.1002/bdm.472

Moran, A. P. (2004). Sport and exercise psychology a critical introduction. New York: Taylor \& Francis Group. https://doi.org/10.4324/9780203380246

Muis, K. R., Winne, P. H., \& Ranellucci, J. (2016). The role of calibration bias and performance feedback in achievement goal regulation. International Education Research, 4, 14-36. https://doi.org/10.12735/ier.v4i1p14

Mupira, P., \& Ramnarain, U. The effect of inquiry - based learning on the achievement goal - orientation of grade 10 physical sciences learners at township schools in South Africa. Journal of Research in Science Teaching.

Nakip M. (2006). Pazarlama Araştırmaları: Teknikler ve (SPSS Destekli) Uygulamalar. Seçkin Yayıncılık, Ankara.

Nasiri, E., Pour-Safar, A. L. I., Taheri, M., Pashaky, A. S., \& Louyeh, A. A. (2017). Presenting the students' academic achievement causal model based on goal orientation. Journal of advances in medical education \& professionalism, 5(4), 195.

Nicholls, J. G. (1984). Achievement motivation: Conceptions of ability, subjective experience, task choice, and performance. Psychological review, 91(3), 328. https://doi.org/10.1037/0033-295X.91.3.328

Nicholls, J. G. (1989). The competitive ethos and democratic education. Harvard University Press.

Pelletier, L.G., Rocchi, M.A., Vallerand, R.J., Deci, E.L., \& Ryan, R.M. (2013). Validation of the revised sport motivation scale (SMS-II). Psychology of Sport and Exercise, 14(3), 329-341. http://dx.doi.org/10.1016/j.psychsport.2012.12.002

Pieschl, S. (2009). Metacognitive calibration - an extended conceptualization and potential applications. Metacognition and Learning, 4, 3-31. http://dx.doi.org/10.1007/s11409-008-9030-4

Pintrich, P. R. (2000). Multiple goals, multiple pathways: The role of goal orientation in learning and achievement. Journal of educational psychology, 92(3), 544. https://doi.org/10.1037/0022-0663.92.3.544

Pintrich, P. R., \& Schunk, D. H. (1996). Motivation in education: Theory, research, and practice. Chapter, 5, 153-197. 
Poondej, C., \& Lerdpornkulrat, T. (2016). Relationship between motivational goal orientations, perceptions of general education classroom learning environment, and deep approaches to learning. Kasetsart Journal of Social Sciences, 37(2), 100-103. https://doi.org/10.1016/j.kjss.2015.01.001

Roberts, G. C. (2012). Motivation in sport and exercise from an achievement goal theory perspective: After 30 years, where are we? In G. C. Roberts \& D. C. Treasure (Eds.), Advances in motivation in sport and exercise (pp. 5-58). Champaign: Human Kinetics.

Schwebel, F. J., Smith, R. E., \& Smoll, F. L. (2016). Measurement of perceived parental success standards in sport and relations with athletes' self-esteem, performance anxiety, and achievement goal orientation: Comparing parental and coach influences. Child Development Research, 2016. https://doi.org/10.1155/2016/7056075

Shin, Y., Kim, M., \& Lee, S. H. (2017). Reflection toward creativity: Team reflexivity as a linking mechanism between team goal orientation and team creative performance. Journal of Business and Psychology, 32(6), 655-671. https://doi.org/10.1007/s10869-016-9462-9

Silva, L., Gomes, A.R., \& Martins, C. (2011). Psychological factors related to eating disordered behaviors: A study with Portuguese athletes. The Spanish Journal of Psychology, 14(1), 323-335. http://dx.doi.org/10.5209/rev_SJOP.2011.v14.n1.29

Solmon, M. A. (1996). Impact of motivational climate on students' behaviors and perceptions in a physical education setting. Journal of Educational Psychology, 84, 261-272. https://doi.org/10.1037/0022-0663.88.4.731

Stone, N. (2000). Exploring the relationship between calibration and self-regulated learning. Educational Psychology Review, 12, 437-475. http://dx.doi.org/10.1023/A:1009084430926

Stuntz, C.P., \& Weiss, M.R. (2015). Social goal orientations, perceived beliefs of significant others, and adolescents' own beliefs about unsportspersonlike play. Journal of Sport Behavior, 38(1), 79-96.

Tok, S., Dal, N., Doğan, E., Yaman, Ç., \& Binboğa, E. (2017). The effect of motivational climate and conscientiousness on athletes' maximal voluntary contraction level of biceps brachii muscle. Current Psychology, 1-6. https://doi.org/10.1007/s12144-017-9675-8

Toros, T. (2004). Reliability and validity of "task and ego orientation in sport questionnaire-TEOSQ" for Turkish athletes. Hacettepe Journal of Sport Science, 15(3), 155-166.

Vieira F., L., Andrade do Nascimento, J. R., Pujals, C., Jowett, S., Codonhato, R., \& Nickenig Vissoci, J. R. (2015). Adaptação transcultural e propriedades psicométricas do questionário de relacionamento treinador-atleta brasileiro (CART-Q) - Versão atleta. [Cross-cultural adaptation and psychometric properties of the Brazilian coach-athlete relationship questionnaire (CART-Q) - Athlete version. In Portuguese.] Brazilian Journal of $\begin{array}{lllll}\text { Kineanthropometry } \quad \& \quad \text { Human } & \text { Performance, } & \text { 17(6), }\end{array}$ https://doi.org/10.5007/1980-0037.2015v17n6p635

Vrugt, A., \& Oort, F. J. (2008). Metacognition, achievement goals, study strategies and academic achievement: pathways to achievement. Metacognition and Learning, 3(2), 123-146. https://doi.org/10.1007/s11409-008-9022-4

Wang, C. J., Chatzisarantis, N. L., Spray, C. M., \& Biddle, S. J. (2002). Achievement goal profiles in school physical education: Differences in self - determination, sport ability beliefs, and physical activity. British Journal of Educational Psychology, 72(3), 433-445. https://doi.org/10.1348/000709902320634401

Zhang, W., Jex, S. M., Peng, Y., \& Wang, D. (2017). Exploring the effects of job autonomy on engagement and creativity: The moderating role of performance pressure and learning goal orientation. Journal of Business and Psychology, 32(3), 235-251. https://doi.org/10.1007/s10869-016-9453-x 


\section{Appendix}

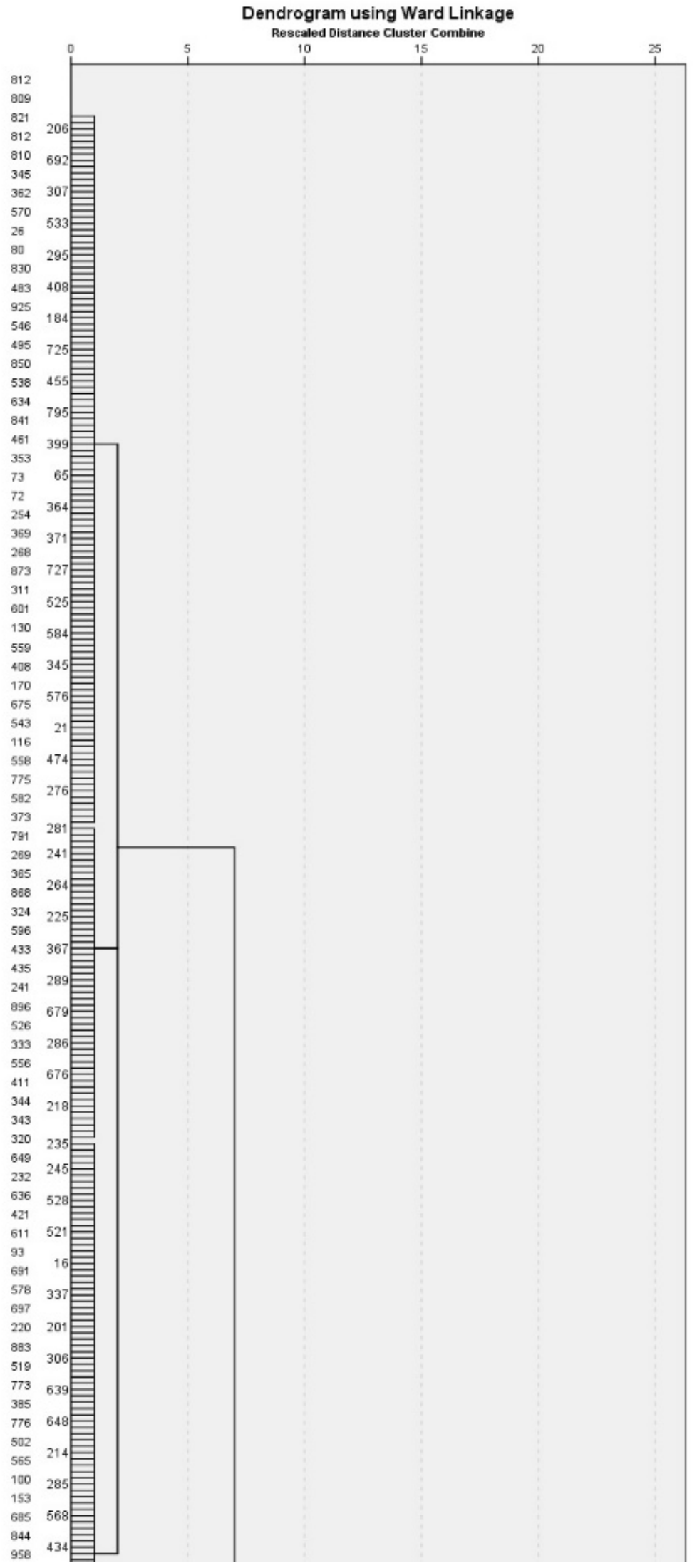




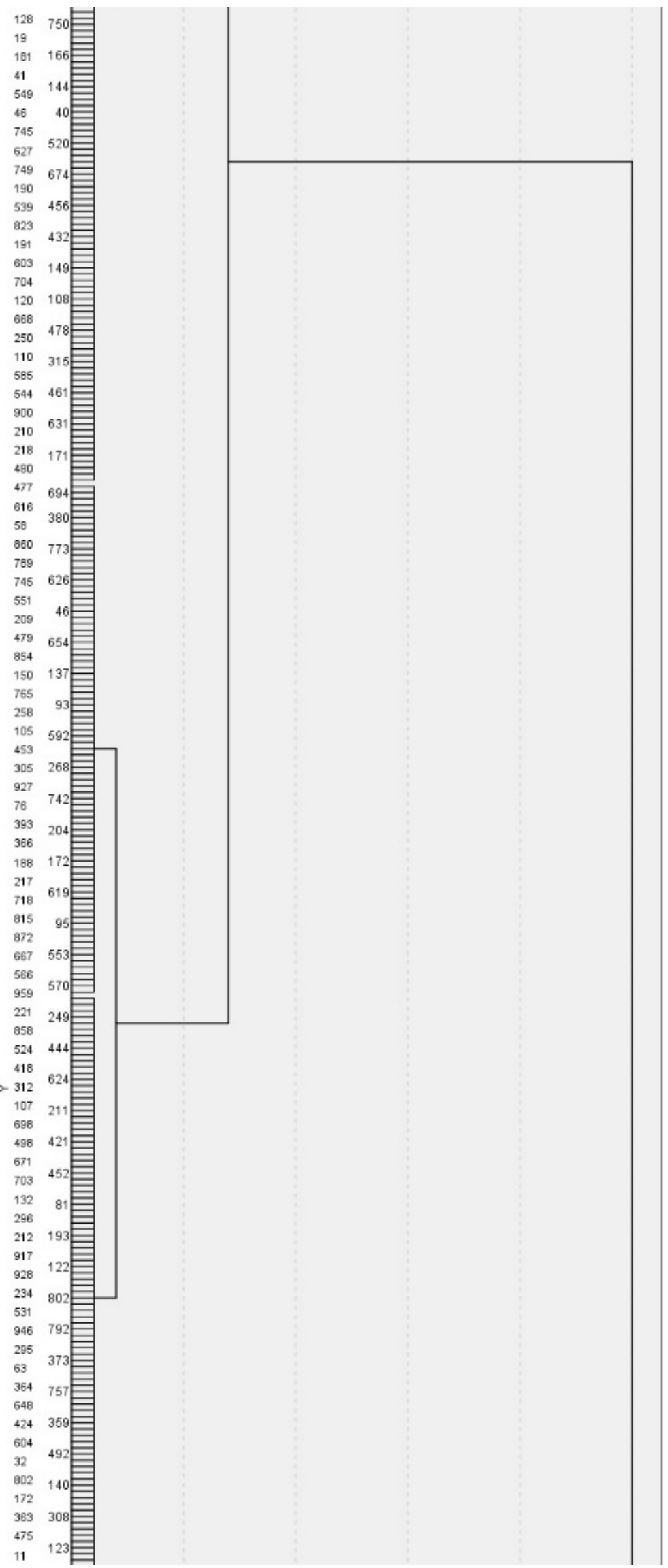


78

78

$936 \quad 782$

352

374

$600 \quad 565$

31

335

$586 \quad 43$

954

$804 \quad 670$

707

721

346

748
131

757

304

736
$816 \quad 681$

677

$860 \quad 732$

$646 \quad 7$

808

916

916
206

908

235

$653 \quad 54$

398

727
907

166

200

156

$650 \quad 5$

680

770

192

159

$\begin{array}{ll}48 & 3\end{array}$

256

38

547

593
392

856

876

$598 \quad 5$

75

117

as

3813

633

9147

314

$942 \quad 78$

74
747

448

167
214

792

851325

722 ,

743

476

149

501
800

782

$205 \quad 1$

18
588

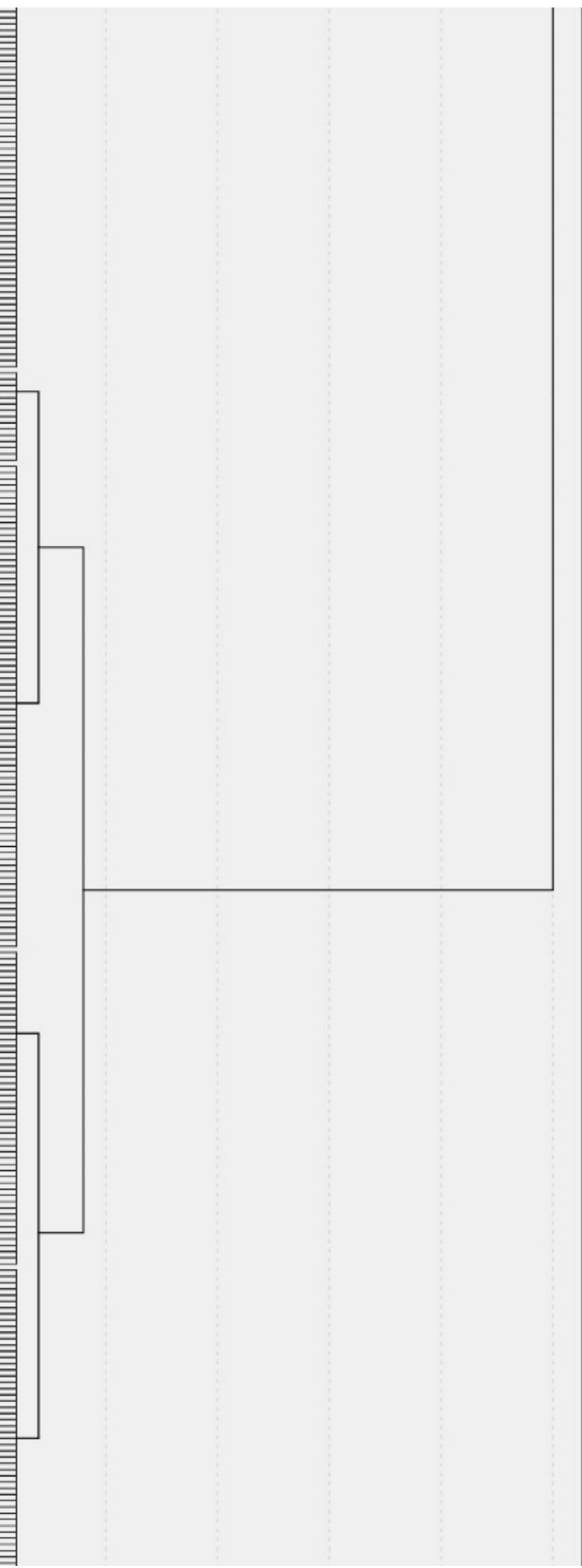




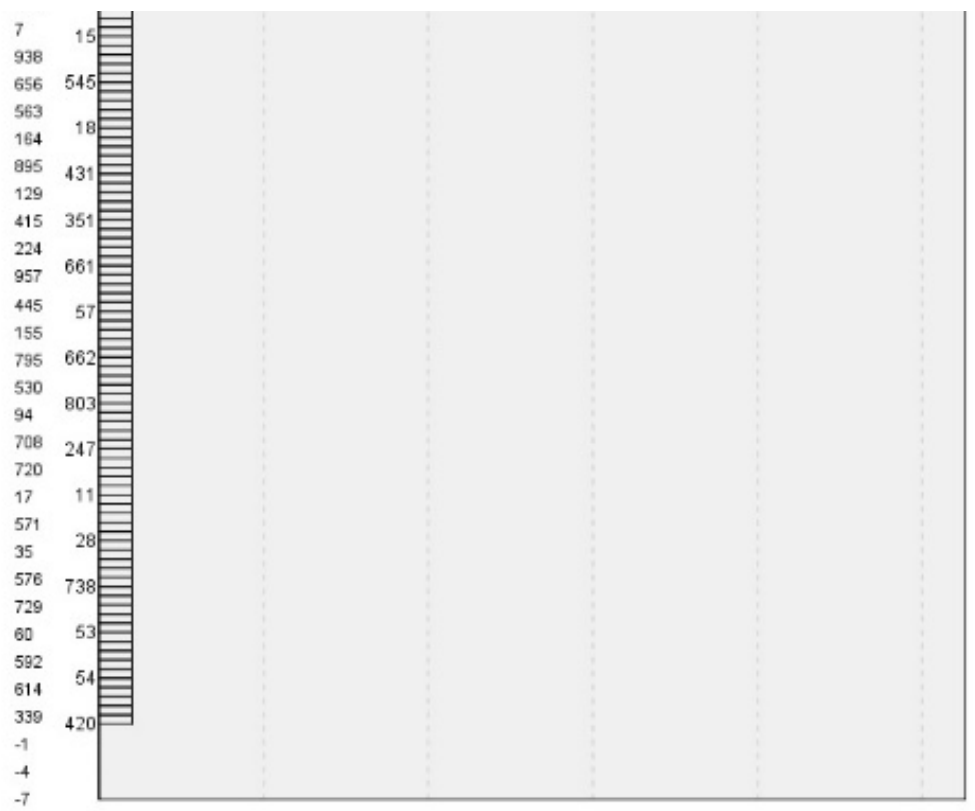

